island to which no archaic coinage has, with certainty, been attributed. Assus. A unique coin with obv. head of Athena; rev. lion's head and the (blundered?) inscription $A \sum \Sigma O O N$. The coin appears, to judge from Dr. Weber's photograph, to have been struck somewhat before 400 B.c. Smyrna and Tenos. Alliance. Ococlia and Bruzas, (Phrygia). Alliance : obv. head and titles of Commodus; rev. OKOK $\Lambda \mathrm{E} \Omega \mathrm{N}$ BP[OrZ]

$H N \Omega N$ OMONOIA. Zeus, holding eagle, and Kybele, holding ears of corn, stauding faciug one an- other; between them, an altar. (Bronze.) On Ococlia, see Ramsay's Hist. Geog. of Asia Minor, pp. 57, 136. - Review of Ridgeway's Origin of Metallic Currency, by B. V. Head. Notice of Revue numismatique, part ii. 1892 , by Head, who suggests that the satrapal coin attributed by Babelon to Abrocomas should be read Abdsasan. This is on the evidence of a recently acquired coin in the British Museum. 'Forgeries of Roman large Brass Coins,' by H. A. Grueber. Describes forgeries of Tranquillina, Didia Clara, etc., lately made in 1 taly.

W. Wroth.

\title{
OBITUARY.
}

\section{PROFESSOR HORT, D.D., LL.D., D.C.L.}

ON Nov. 30, 1892 passed away almost without notice in the daily papers and even in weekly journals, such as the Academy and Athenaeum, which are addressed to a more educated circle, one who will be long remembered in Cambridge as the very embodiment of her ideal of the Christian scholar. From a boy he had been remarkable for an eager thirst after knowledge of every kind, which was witnessed to in his Rugby days by the four first classes in which his name appeared Christmas after Christmas to the awed amazement of his school-fellows, and subsequently by the honours gained in four schools at Cambridge.

The basis of his character was a persistent enthusiasm. He threw his whole heart into everything that he did. As he was intensely alive to impressions received through the senses, which made him an excellent botanical observer, so he was intensely alive to the impressions received through books, which made study to him a continual delight, and enabled him without weariness to get through an amount of what others night have thought drudgery, which is simply astounding to those who have seen the proofs of it in his library. With Hort enthusiasm was not merely receptive and emotional: it was combined with extraordinary activity of the imaginative and reasoning powers, and controlled by a no less active exercise of the critical faculty, which compelled him to test every statement by the strictest canons of evidence and continually to compare his own work with the highest conceivable standard of excellence. It was this constant reference to a scarcely attainable standard which made him so scrupulously fastidious in his work, and so modest in regard to his own achievements, while at the same time it so unfortunately limited the output of his labours during his own lifetime. The ' intellectual conscientiousness,' which Prof. Grote noted as the distinguishing feature in his friend Leslie Ellis, showed itself not less strongly in Hort in 'the feeling of dissatisfaction at anything being confusedly put, or not thoronghly worked out.' $H$ had too the faith which Grote regarded as the mark of the true philosopher, 'non desperavit de veritate: he believed in truth enough to be willing to labour for it and to forego any substitutes for it.' In his quest after truth he paid no regard to preconceived opinions, or to the popularity or otherwise of the results of inquiry, believing that in theology, as in other departments of thought, the truth could only be ascertained by following humbly the guidance of facts.

'This single-minded devotion to truth and indifference to outside opinion had its natural results. To the world in general he was unknown; to the great majority even of scholars and divines he was known only by report as the author of two extremely abstruse volumes; but it has been truly said that "by all who have studied the problems of the New Testament and of early Christian literature, it will be felt that in the death of Dr. Hort the world of letters has lost the Christian scholar that could least be spared, the voice that, wherever it made itself heard, all were compelled to give attention to.' What he was to his own pupils may be judged from three most interesting notices which appeared almosi im- 
mediately after his death, the first in the Cambridge Review of Dec. 8 by Prof. Ryle, the second in the Guardian of Dec. 7 and 14 by the Rev. J. O. Murray, the third in the Expositor for Jan. by Prof. Armitage Robinson. It is mainly from these notices, especially from that of Mr. Murray, that the brief memoir which follows bas been compiled, and I cannot bring my own remarks to a close better than by quoting words, which may raise a doubt whether Hort was more to be congratulated on the friendship and fellowship of Westcott and Lightfoot in his life, or on the knowledge that after his death his work would continue to be carried on in his own spirit by the scholars whom he had trained.

The first quotation shall be from Prof. Armitage Robinson :-

'No wonder that a kind of cult arose among those who were privileged to enter his study or his lecture-room... He would guide where guidance was really needed; be would always sympathize and encourage; he never seemed surprised at knowledge or ignorance; never shocked at the expression of most crude opinions. But on the other hand he seemed to regard the formation of opinion as a very sacred thing; he refused to prejudice by arguing with one who was beginning the study of the subject. "What book would you recommend as the best introduction to the Synoptic question ?" After some sympathetic preface came the words never to be forgotten, "I should advise you to take your Greek Testament, and get your own view of the facts first of all."...To a confession of ignorance as a disqualification for a certain undertaking, he replied in a careful letter: "nor need you be perturbed by the consciousness of ignorance, though you must not expect to get free from it. As far as my experience goes, the more one learns, the more one's sense of ignorance increases, and that in more than double measure. We can only go blunderingly on according to the best of our lights, hoping that sooner or later the blunders will get corrected by others." '

The second is from Professor Ryle:-

'What we younger men in Cambridge owe to him, to his example, to his desire and eagerness to help and to sympathize in life and in study, to the influence of his character, we can never say in words: wo can simply pray that, though in a way quite unworthy of so noble a leader and so inspiring a master-worker, it may be given us to do a little, during our short day, in something of the same spirit that animated Dr. Hort.'

J. B. M.

Fenton John Antony Hort, son of Mr. Fenton Hort of Dublin and afterwards of Cheltenham, and great-graudson of the Archbishop of Tuam of the same name, was born April 23, 1828, educated at Laleham under Arnold's brother-in-law, the Rev. J. Buckland, and at Rugby under Arnold and Tait. Next to that of Arnold himself, the most marked influence in his school days came from Bonauny Price, at that time master of the Twenty, the form immediately below the Sixth. To the end of his life his old master recalled with delight the memory of the bright eyes and keen, inquiring, ever active spirit of one of the most attractive pupils he had ever known. From Rugby he passed to Trinity College, Cambridge, in October 1846. Westcott was two years his senior, and Hort read with him for one term befure taking his degree in 1850. Lightfoot came up in 1847, and Hort and Lightfoot were elected Fellows together in 1852. Hort's university degree included three first classes, in Classics (bracketed third), in Moral Science, and in Natural Science, beside a Junior Optime in the Mathematical Tripos, in which be was unable to show his full powers, heing still weak from scarlet fever and allowed only to take the papers in the lower subjects. Nor were his energies and interests confined to the regular studies of the University. He belonged to one or two Essay Clubs and was for a tine President of the Union, on the walls of which his portrait is to be seen. He was ordained at Oxford in 1854. In the same yearappeared the first number of the Journal of Classical and Sacred Philology, edited by him in conjunction with lightfoot and the present Professor of Latin. It was about the same time that he and Dr. Westcott formed the design of bringing out a critical edition of the Greek Testament, as well as of joining with Lightfoot in the elucidation of the Epistles of the N.T., St. John being undertaken by Westcott, St. Paul by Lightfoot, and the Catholic Epistles by Hort.

On his marriage in 1857 he succeeded to the College living of St. Iypolyt's, near Hitchin, where he remained for fifteen years, returning to Cambridge in 1872 as Fellow and Divinity Lecturer of Emmanuel College. He became Hulsean Professor in 1878 and 
succeeded Dr. Swainson in the Lady Margaret Chair in 1887. The list of his printed writings appended below will show the general line of his studies during this period; besiden these, there were the lectures, delivered in College or before the University; and much time and labour were devoted to assisting his fellow-workers in the same department, both in England and abroad. $\mathrm{Up}$ to the year 1881 his chief work was of course the preparation for his edition of the Greek Text of the New Testament. The principles on which it is based are explained and illustrated in the Introduction and Appendix, which were drawn up by Dr. Hort. The decisions as to the readings adopted are the result of the joint labours of the two editors, who compared together the conclusions they had independently arrived at; and where on comparison these conclusions were found to disagree, the differences were discussed in writing, until either the divergence disappeared, or a final contrariety of judgment was declared. The vast collections which formed the basis of these arguments, as well as the important correspondence itself, are most carefully preserved. Another constant correspondent was Tregelles, whose edition of the Greek Testament, with the exception of the first part, was enriched from the stores of early patristic references accumulated in Dr. Hort's margins. The posthumous Part vii. of 'Tregelles' edition, containing the Prolegomena and embodying in the Addenda and Corrigenda a careful review of the whole evidence collected in Tregelles' notes on the Text, besides incorporating a large amount of fresh material, was compiled and edited by Dr. Hort with the assistance of Mr. Streane in 1879. And the proof-sheets of Dr. Gregory's Prolegomena to Tischendorf's eighth edition, in the two parts already published, have also had the advantage of his generous supervision.

In 1870 he became a member of the Committee appointed to revise the Authorized Version, and for years he was one of the most indefaligable and influential attendants at its sittings. After the Revised Version of the New Testament was published in 1881 , he took part in the revision of the Apocrypha, the books assigned to the Cambridge Committee being Wisdom and the Second Book of Mlaccabees, and his fellowworkers being Dr. Westcott and Dr. Moulton. The work on the Book of Wisdom was only brought to a conclusion in the month before his death. The subjects of the Lectures which he delivered in College and before the University were mainly confined to the
Greek Testament and the Fathers. In many cases they did not go beyond a careful and complete introduction, worked out at first hand from the original sources, and including a series of short, clear, delicate appreciations of the work of his predecessors in the same field. As an expositor he had a unique power of taking a phrase to pieces, and tracing the history of each of its significant parts, tirst singly and then in conjunction. Having thus helped his class to an understanding of the wealth of association that had gathered round each phrase by the time that the author came to use it, he would then replace them in their context; and it was often surprising to notice the richness of meaning which this truly his. torical method of treatment brought to light in passages which might otherwise have been passed over as common-place and unimportant.

During the last two years of his life he suffered from constant ill-health. His latest work was the article on his friend and colleague, Bp. Lightfoot, for the Dictionary of Vational Biography. The effort to produce always told severely upon him, and in this case the strain was intensified by the necessity of working against time.

The following chronological list of his printed work is drawn up by $\mathrm{Mr}$. Murray.

1851. Christian Socialist, October 11, 1851. "The Message of the Church to Landlords.' Letter enclosing a 'Prayer for Laudlords,' from a primer of Edw. VI., in the column of 'Free Correspondence.'

In the same year he contributed to the Annals of N'atural History (ser. II. vol. vii. p. 374) an identification of a new bramble known to botanists as rubus imbricatus (Hort).

1854. Journal of Classical and Sacred Philology. Vol. I. Pearson's Marginalia. (1) and (2).

Short Notices of Dressel's ed. of Clementine Homilies, of Ueltzen's ed. of Constitutiones Apostolicae, and of a tract (historical) by H. W. J. Thiersch.

1855. Journal of Classical and Sacred Philology. Vol. 2. Review of Tregelles on printed text of $\mathrm{N}$. T.

Notices of Tischendorf's Anecdota and of Baumgarten on the Acts.

Edits H. Mackenzie's Hulsean Essay on the Beneficial Influence of the Clergy during the First Ten Centuries.

1856. 'Tintern, October, 1855.' A poem included in the volume entitled 'Peace in War. In Memoriam L. R.' (Macmillan.) 
Journal of Classical and Sacred Philology. Vol. 3. (a) On the date of Justin Martyr.

(b) A frugment of S. Dionysius of Alexandria, discovered in Univ. Library.

(c) A study of the word 'Limes' in elucidation of Tac. Ann. i. 50.

(d) On the transfation of the Aorist,including a full discussion of the meanings of $v \hat{v} v$. Cambridge Essays. Elaborate article on 'Coleridge.'

1857. Letter to Rev. J. Ll. Davies. On the Tenure of Fellowships and on Church Patronage in Trinity College.

1857-60. Journal of Classical and Sacred Philology. Vol 4. (a) Review of Tregelles (Part i.) and Tischendorf. Ed. 7 (1855-7).

(b) Identification of the Latin Version of the lost Commentary of Theodore of Mopsuestia on ten of St. Paul's Epistles.

(c) Review of Scrivener's edition of the Codex Augiensis, and Tischendorf, Ed. 7 (1859). (Concluding parts.)

1862. Thoughts on the Revised Code of Education: its purposes and probable effects.

1864. Macmillan's Magazine. 'The Last Days of Simon de Montfort : a Fragment.'

1869. Journal of Philology. Controversy with Lightfoot on the Doxology at the end of the Romans (xvi. 25-27).

1873. Edits Memorials of the late W. B. Marriott, including (1) Grinfield Lectures on Terms of Gift and Offering ; (2) Treatise on the Holy Eucharist.

1876. Two Dissertations. I. On Movoye$\nu \grave{\eta} s \Theta \epsilon o ́$ in Scripture and Tradition.

II. On the 'Constantinopolitan Creed' and other Eastern Creeds of the Fourth Century.

1877. Dict. of Christian Biogr. Vol. I. 60 articles, chielly on Gnostics, including Apelles, Bardesanes (Bardaisan), Basilides.

1879. Prolegomena to Tregelles. Selected and edited with the help of Mr. Streane. 1881. May. The New Testament in Greek (with Dr. Westcott).

August. 'Introduction' and Appendix.

1885. The New Testament in Greek. Smaller edition, with fresh appendix.

1885. Times, June 25, July 16. Letters on the Fayoum Fragment.

1887. Academy, Feb. 26, June 11.

' Codex Amiatinus.'

1889. Sermon in the College Chapel.
- The Growth of a College into a Temple in the Universal Temple.'

1890. Sermon at Dr. Westcott's Consecration. 'The Sense and Service of Membership the Measure of True Soundness in the Body.'

1892. Dict. of' National Biography. 'J.

B. Lightfoot.' 'Title-page dated 1893.

No date. A Paper on Hebrews i. 8.

We are glad to learn from Dr. Hort's executors that he has left behind him a large mass of MS., much of which it is hoped may be shortly published. This includes, beside the four Hulsean Lectures on the Way, the Truth, and the Life, which are already in type, (1) Lectures on the N.T.; (2) Lectures on the Fathers; (3) Lectures on the history of the Church.

(1) The most important under this head are :-

The Epistle to the Romans (Easter term 1886 ), amounting to 928 vo pages of MS.

First three chapters of the Apocalypse, 129 pages.

Ephesians, 130 pages.

St. James, 3018 vo, and 254 4to pages.

St. Peter, 1st Epistle, 300 pages.

There are also 53 pages on 1 Timothy, 43 on 1 Corinthians, some notes on the Galatians and on N.T. Lexicography.

(2) Clementine Recognitions, 162 pages and a great quantity of notes.

Tertullian against Marcion, 120 pages.

Tatian 76 pages and loose notes.

There are also some popular Lectures on the Fathers delivered before the Cambridge Clergy Training School, notes on Cyril of Jerusalem, Clement of Alexandria, and Origen against Celsus.

(3) Judaistic Christianity (1886 and 1887), 218 pages.

Early Conceptions and Early History of the Christian ék $\kappa \lambda \eta \sigma^{\prime} i a(1889), 305$ pages.

(4) Besides these, there are the 'pièces justificatives,' already referred to, of the readings adopted in the Greek Testanuent, together with the correspondence which passed between him and Dr. Westcott on the same subject; a mass of other correspondence on points of literary or scientific interest; a great quantity of notes on the revision of the N.T. and Apocrypha ; Notebooks and Marginalia \&c., from all of which it is hoped that selections will hereafter be made for publication. 